\title{
EFFECT OF SODIUM FLUORIDE ON SOME MORPHOLOGICAL AND PHYSIOLOGICAL PARAMETERS OF 10-DAY-OLD SEEDLINGS OF VARIOUS PLANT SPECIES
}

\section{WPŁYW FLUORKU SODU NA NIEKTÓRE PARAMETRY MORFOLOGICZNE I FIZJOLOGICZNE W LIŚCIACH 10-DNIOWYCH SIEWEK RÓŻNYCH GATUNKÓW ROŚLIN}

\author{
Department of Plant Physiology and Biochemistry, West Pomeranian University \\ of Technology, Szczecin, Poland \\ ${ }^{1}$ Department of Plant Genetics, Breeding and Biotechnology, West Pomeranian \\ University of Technology, Szczecin, Poland
}

\begin{abstract}
Streszczenie. Fluor ze względu na wysoką elektroujemność jest jednym z najbardziej toksycznych dla roślin pierwiastków. Związki fluoru po wniknięciu do tkanki roślinnej mogą powodować wiele zmian fizjologicznych i biochemicznych. Celem niniejszej pracy było określenie wpływu $10 \mathrm{mM}$ fluorku sodu ( $\mathrm{NaF}$ ) na parametry morfologiczne (długość korzenia, długość siewki) oraz parametry biochemiczne (zawartość proliny, chlorofilu całkowitego i karotenoidów) w liściach 10-dniowych siewek różnych gatunków roślin rosnących w warunkach laboratoryjnych. Wyniki doświadczenia wykazały, że fluorek sodu niekorzystnie wpłynął na parametry morfologiczne i biochemiczne testowanych roślin, w porównaniu z próbą kontrolną. Wśród badanych roślin trzy gatunki (jęczmień, rzodkiew, łubin) charakteryzowały się zwiększoną tolerancją na NaF w odniesieniu do innych testowanych roślin. Natomiast mniejszą tolerancję na działanie soli NaF wykazały pszenica, rzodkiewka, pomidor, lucerna i słonecznik.
\end{abstract}

Key words: fluoride, stress plant, morphological parameters, proline, chlorophyll, carotenoids. Słowa kluczowe: fluor, stres roślin, parametry morfologiczne, prolina, chlorofil, karotenoidy.

\section{INTRODUCTION}

Fluoride $(F)$ is a substance commonly found in the environment of the earth, which occurs naturally in soil, water and atmosphere. The elevated concentrations of fluoride in environment were found to be responsible for serious health problems in many parts of the world. Fluoride shows significant interaction with plants and adversely affects their various physico-biochemical parameters, growth and productivity (Gadi et al. 2012; Sant'Anna-Santos et al. 2013; Das et al. 2015). The most important source of fluoride in agriculture are industries, coal-fired power stations and especially fertilizers (superphosphates) produced by factories.

Even at fairly low ambient concentrations, fluoride can cause a number of physiological and biochemical changes in plants without visible signs of injury. The $\mathrm{F}$ is not considered as

Corresponding author - Adres do korespondencji: Beata Smolik, Department of Plant Physiology and Biochemistry, West Pomeranian University of Technology, Szczecin, Juliusza Słowackiego 17, 71-434 Szczecin, Poland, e-mail: beata.smolik@zut.edu.pl. 
an essential element for plants (Jha et al. 2013). High levels of $F$ inhibit germination, cause ultrastructure malformations, reduce photosynthetic capacities, alter membrane permeability, reduce productivity, decrease biomass, and inflict other physiological and biochemical disorders in plants (Sabal et al. 2006; Divan et al. 2008; Bhargawa and Bhardwaj 2010; Datta et al. 2012). Generally, F can modify or disrupt plant metabolic. Most of the plants are rather sensitive to F (Gautam and Bhardwaj 2010). Certain physiological processes are known to be markedly affected by $\mathrm{F}$, including, decreased plant growth, chlorosis, leaf tip burn, and leaf necrosis. $F$ is absorbed by plant roots and then transported via xylematic flow to the transpiratory organs, mainly leaves, where it can be accumulated with adverse effects (Gupta et al. 2009).

The aim of this study was to determine the effect of $10 \mathrm{mM}$ sodium fluoride $-\mathrm{NaF}$ on the morphological and biochemical parameters of 10-day-old seedlings of various species of crop plants, and assessment of sensitivity to the presence of fluoride ions in the environment, which is the basis for the selection of certain plant species tolerant to unfavorable environmental conditions.

\section{MATERIAL AND METHODS}

The experiment was conducted in January 2014 in the laboratory of the Department of Plant Physiology and Biochemistry and Department of Plant Genetics, Breeding and Biotechnology at the West Pomeranian University of Technology in Szczecin, Poland. The study material included undressed seeds collected from 10 plant species commonly used in testing the toxicity (phytotoxicity): radish (Raphanus sativus L. var.'Carmen'), radish (Raphanus sativus L. var. Minowase Summer Cross'), barley (Hordeum vulgare L. var. 'Eunova'), rye (Secale cereale L. var. 'Bojko'), wheat (Triticum aestivum L. var. 'Bryza'), blue lubine (Lupinus angustifolius L. var. 'Caro'), sunflower (Helianthus annuus L. var. 'Bella'), cucumber (Cucumis sativus L. var. 'Ela'), alfalfa (Medicago sativa L. var. 'Triade'), tomato (Lycopersicon esculentum L. var. 'Faworyt').

Seeds of each species were surface-sterilized with $70 \%(\mathrm{v} / \mathrm{v})$ ethanol solution for $30 \mathrm{~s}$ and then rinsed with sterile water. After the preliminary disinfection, seeds were soaking for 15 minutes in $10 \%(\mathrm{v} / \mathrm{v})$ solution of sodium hypochlorite $(\mathrm{NaOCl})$, after rinsing three times in sterile water. Next, seeds were placed on Petri dishes $(\varnothing 10 \mathrm{~cm})$ lined with filter paper and moistened with $30 \mathrm{~cm}^{3}$ sterile water (control) and with fluoride solution. The experiments were repeated 3 times. 30 seeds were used per treatment, including control.

The Petri dishes with the seeds were transferred to growth chamber at the Department of Plant Genetics, Breeding and Biotechnology, West Pomeranian University of Technology in Szczecin. The Petri dishes with the seeds were stored in a growth chamber at a constant temperature of $25^{\circ} \mathrm{C}$ in white light $\left(40 \mu \mathrm{mol} \cdot \mathrm{m}^{-2} \cdot \mathrm{s}^{-1}\right)$ for $16 \mathrm{~h}$ and $8 \mathrm{~h}$ dark per a day.

After ten days, plants were removed and washed with deionized distilled water. Biometric measurements were performed, in which the following parameters were determined: shoot length, root length and biochemical parameters: proline, total chlorophyll and carotenoids contents. 
Determination of proline. Proline content was measured according to the method of Bates (1973). Fresh seedlings $(0.5 \mathrm{~g})$ were ground in $1.5 \mathrm{~cm}^{3}$ of aqueous sulfosalicylic acid $3 \%(\mathrm{w} / \mathrm{v})$, and proline was estimated by ninhydrin reagent. The samples extracted with toluene and the absorbance of the toluene phase was read at $520 \mathrm{~nm}$. The concentration of proline was calculated from a standard curve and expressed as $\mu \mathrm{mol} \cdot \mathrm{g}^{-1}$ fresh weight.

Determination of pigments. The extraction of leaf pigments was performed with $80 \%$ (v/v) acetone. Chlorophyll $a, b$ and carotenoids content was determined spectrophotometrically at 663,645 and $440 \mathrm{~nm}$, respectively. The concentration of total chlorophyll was calculated according to the method of Arnon et al. (1956) in modification of Lichtenthaler and Wellburn (1983), whereas the concentration of carotenoids - according to the method of Hager and Meyer-Berthenrath (1966). The pigment concentrations were expressed as $\mu \mathrm{g} \cdot \mathrm{g}^{-1}$ fresh weight.

Statistical analysis. The significance of differences was determined by means of variance analysis and Tukey's test, at the level of significance of $\alpha=0.05$.

\section{RESULTS AND DISCUSSION}

Fluoride $(F)$ contamination of soil, water, and vegetation, has been a continuing problem in the world. In case of plant certain physiological processes are known to be markedly affected (McNulty and Newman 1961; Hadujue 1966; Jacobson et al. 1966; Elloumi et al. 2005). The importance of seed germination in plant growth is widely recognized and its study has been used as a model for investigating $F$ toxicity by various authors (Wang et al. 1991; Wilde and Yu 1998; Gulzar and Khan 2001; Rubio-Casal et al. 2003; Elloumi et al. 2005; Gupta et al. 2009). Many plants are especially sensitive to $F$ pollution. Certain physiological processes, e.g., plant growth and chlorophyll contents are known to be markedly decreased by F.

Evaluating seedling length in the studied plant species it was found that presence of fluoride resulted to decrease of seedling length in the tested plants compared to the control plants. Higher reduction of seedling length was observed in wheat 58.22\% (Table 1).

The application of sodium fluoride led to a significant decrease $(p \leq 0.05)$ of root length of all examined plant species compared to the control plants. The highest decrease of root length was found in radish Carmen (65.95\%), wheat (62.82\%), cucumber (86.20\%), sunflower $(78.19 \%)$, and alfalfa $(65.17 \%)$ (Table 1$)$. On the other side, in radish 'Minowase Summer Cross', rye, barley and lupine no statistically significant difference was observed in the root length of plants in comparison to the control and combination with $10 \mathrm{mM} \mathrm{NaF}$

This kind of variation in sensitivity to $\mathrm{F}$ among different plant species has been obtained in Eucalyptus species, wheat, mustard, Bengal gram (Ivinskis and Murray 1984; Pant et al. 2008).

Results obtained in this experiment indicates that the present of fluoride in the medium increased the proline content in most seedlings of the tested plants in comparison to the control (Table. 2). The highest proline concentration was observed in radish (var. Carmen), sunflower and tomato. Proline is known as a protein thereby provide protection against stress by acting as a source of nitrogen storage compound. According to many authors (Elloumi et al. 2009; Bhargava and Bhardwaj 2010; Gadi et al. 2012; Datta et al. 2012) when plants were treated with $0.01 \mathrm{mM}$ to $8.0 \mathrm{mM}$ of fluoride, free proline concentration in seedlings was increased. 
Table 1. Morphological features of examined plant species under stress conditions induced with $10 \mathrm{mM} \mathrm{NaF}$ salt solution Tabela 1. Cechy morfologiczne badanych gatunków roślin poddanych działaniu stresu przez zastosowanie $10 \mathrm{mM}$ roztworu soli NaF

\begin{tabular}{|c|c|c|c|c|c|c|}
\hline \multirow{2}{*}{$\begin{array}{l}\text { Plant species } \\
\text { Gatunek rośliny }\end{array}$} & \multicolumn{3}{|c|}{$\begin{array}{c}\text { Shoot length } \\
\text { Wysokość siewki [cm] }\end{array}$} & \multicolumn{3}{|c|}{$\begin{array}{c}\text { Root length } \\
\text { Długość korzenia [cm] }\end{array}$} \\
\hline & $\begin{array}{c}\text { control } \\
\text { kontrola }\end{array}$ & $10 \mathrm{mM} \mathrm{NaF}$ & $\operatorname{LSD}_{0.05}$ & $\begin{array}{l}\text { control } \\
\text { kontrola }\end{array}$ & $10 \mathrm{mM} \mathrm{NaF}$ & LSD $_{0.05}$ \\
\hline $\begin{array}{l}\text { Radish - Rzodkiew zwyczajna (Raphanus sativus L. cv. } \\
\text { 'Carmen') }\end{array}$ & $1.95 \pm 0.82$ & $1.03 \pm 0.22$ & $0,58^{*}$ & $7.90 \pm 2.51$ & $2.69 \pm 1.41$ & $3.52^{*}$ \\
\hline $\begin{array}{l}\text { Radish - Rzodkiew zwyczajna (Raphanus sativus L. cv. } \\
\text { 'Minowase Summer Cross') }\end{array}$ & $2.31 \pm 1.24$ & $1.88 \pm 0.43$ & $0,70^{*}$ & $2.34 \pm 1.44$ & $2.11 \pm 0.77$ & n.d. \\
\hline $\begin{array}{l}\text { Barley - Jęczmień zwyczajny (Hordeolum vulgare L. cv. } \\
\text { 'Eunova') }\end{array}$ & $3.42 \pm 1.24$ & $3.09 \pm 0.58$ & n.d & $2.55 \pm 0.83$ & $2.18 \pm 0.65$ & n.d. \\
\hline Rye - Żyto zwyczajne (Secale cereale L. cv. 'Bojko') & $2.96 \pm 1.41$ & $1.67 \pm 0.58$ & n.d & $4.73 \pm 1.25$ & $2.53 \pm 0.82$ & n.d. \\
\hline $\begin{array}{l}\text { Wheat - Pszenica zwyczajna (Triticum aestivum L. cv. } \\
\text { 'Bryza') }\end{array}$ & $12.35 \pm 1.93$ & $5.16 \pm 3.54$ & $1,97^{*}$ & $7.53 \pm 3.65$ & $2.8 \pm 1.93$ & $2.81^{*}$ \\
\hline $\begin{array}{l}\text { Blue lubine - Łubin wąskolistny (Lupinus angustifolius L. cv. } \\
\text { 'Caro') }\end{array}$ & $3.91 \pm 1.57$ & $2.4 \pm 0.52$ & $0,81^{*}$ & $1.5 \pm 0,65$ & $1.28 \pm 0.98$ & n.d. \\
\hline $\begin{array}{l}\text { Sunflower - Słonecznik zwyczajny (Helianthus annuus L. cv. } \\
\text { 'Bella') }\end{array}$ & $1.35 \pm 0.47$ & $0.67 \pm 0.29$ & $0,36^{*}$ & $5.18 \pm 2.38$ & $1.13 \pm 0.66$ & $2.14^{*}$ \\
\hline Cucumber - Ogórek (Cucumis sativus L. cv. 'Ela') & $2.07 \pm 0.88$ & $1.11 \pm 0.23$ & $0,70^{*}$ & $9.8 \pm 2.4$ & $1.27 \pm 0.89$ & $1.98^{*}$ \\
\hline Alfalfa - Lucerna (Medicago sativa L. cv. 'Triade') & $0.86 \pm 0.41$ & $0.57 \pm 0.28$ & $0,23^{*}$ & $3.33 \pm 1.61$ & $1.16 \pm 0.78$ & $0.90^{*}$ \\
\hline Tomato - Pomidor (Lycopersicon esculentum L. cv. 'Faworyt') & $2.47 \pm 0.52$ & $2.1 \pm 0.71$ & n.d. & $7.82 \pm 4.39$ & $4.10 \pm 1.43$ & $1.96^{*}$ \\
\hline
\end{tabular}

LSD 0.05 - less significant difference $\alpha<0.05$ - najmniejsza istotna różnica $\alpha<0.05{ }^{*}$ significant difference - różnice istotne; n.d. - nonsignificant difference - różnice nieistotne; \pm SD - standard deviation - odchylenie standardowe. 
Table 2. Free proline concentration in seedlings of different species growing under stress conditions induced with $10 \mathrm{mM} \mathrm{NaF}$

Tabela 2. Stężenie wolnej proliny w siewkach różnych gatunków roślin rosnących w warunkach stresu wywołanego przez zastosowanie $10 \mathrm{mM} \mathrm{NaF}$

\begin{tabular}{|c|c|c|c|}
\hline \multirow{2}{*}{$\begin{array}{l}\text { Plant species } \\
\text { Gatunek rośliny }\end{array}$} & \multicolumn{3}{|c|}{$\begin{array}{l}\text { Proline - Prolina } \\
{\left[\mu \mathrm{mol} \cdot \mathrm{g}^{-1}\right]}\end{array}$} \\
\hline & $\begin{array}{l}\text { control } \\
\text { kontrola }\end{array}$ & $10 \mathrm{mM} \mathrm{NaF}$ & $\mathrm{LSD}_{0.05}$ \\
\hline $\begin{array}{l}\text { Radish - Rzodkiew zwyczajna (Raphanus sativus L. cv. } \\
\text { 'Carmen') }\end{array}$ & $12.01 \pm 0.58$ & $19.84 \pm 0.95$ & $1.52^{*}$ \\
\hline $\begin{array}{l}\text { Radish - Rzodkiew zwyczajna (Raphanus sativus L. cv. } \\
\text { 'Minowase Summer Cross') }\end{array}$ & $57.22 \pm 0.25$ & $57.47 \pm 0.01$ & n.d. \\
\hline $\begin{array}{l}\text { Barley - Jęczmień zwyczajny (Hordeolum vulgare L. cv. } \\
\text { 'Eunova') }\end{array}$ & $25.92 \pm 0.38$ & $24.02 \pm 1.46$ & n.d. \\
\hline Rye - Żyto zwyczajne (Secale cereale L. cv. 'Bojko’) & $10.21 \pm 0.42$ & $12.12 \pm 0.16$ & $0.62^{*}$ \\
\hline $\begin{array}{l}\text { Wheat - Pszenica zwyczajna (Triticum aestivum L. cv. } \\
\text { 'Bryza') }\end{array}$ & $3.21 \pm 0.33$ & $4.48 \pm 0.21$ & $0.53^{*}$ \\
\hline $\begin{array}{l}\text { Blue lubine - Łubin wąskolistny (Lupinus angustifolius L. cv. } \\
\text { 'Caro') }\end{array}$ & $35.27 \pm 3.51$ & $36.26 \pm 4,00$ & n.d. \\
\hline $\begin{array}{l}\text { Sunflower - Słonecznik zwyczajny (Helianthus annuus L. cv. } \\
\text { 'Bella') }\end{array}$ & $7.91 \pm 0.30$ & $13.64 \pm 0.52$ & $0.82^{*}$ \\
\hline Cucumber - Ogórek (Cucumis sativus L. cv. 'Ela') & $3.88 \pm 0.29$ & $4.71 \pm 0.47$ & $0.75^{\star}$ \\
\hline Alfalfa - Lucerna (Medicago sativa L. cv. 'Triade') & $1.17 \pm 0.30$ & $2.24 \pm 0.28$ & $0.57^{*}$ \\
\hline $\begin{array}{l}\text { Tomato - Pomidor (Lycopersicon esculentum L. cv. } \\
\text { 'Faworyt') }\end{array}$ & $12.01 \pm 0.58$ & $19.84 \pm 0.95$ & $1.52^{*}$ \\
\hline
\end{tabular}

Explanations see Table 1 - Objaśnienia zob. tab. 1.

As it is seen in Table 3 total chlorophyll content in leaves decreased monotonically. The largest decrease in chlorophyll content was observed in wheat. This may be due to the break down of chlorophyll during stress or due to inhibition of chlorophyll biosynthesis, which is a primary symptom of fluoride-induced chlorosis. Similar results were obtained in Cyamopsis tetragonoloba L. var. 'RGC-197' (Sabal et al. 2006), Amygdalis communis L. (Elloumi et al. 2005) and Triticum aestivum L. var. 'Raj. 4083' (Bhargava and Bhardwaj 2010). In this experiment also concentration of carotenoids in seedlings of different species was smaller in comparison to the control plants (Table 3 ).

\section{CONCLUSIONS}

The study showed that $10 \mathrm{mM}$ solution of $\mathrm{NaF}$ had negative influence on growth and development, as well as biochemical parameters of 10-day-old seedlings of the plant species tested under laboratory conditions. On the basis of the obtained results five species tested (wheat, radish - 'Carmen', alfalfa, sunflower, tomato) has been selected as a sensitive and three (barley, radish - 'Minowase Summer Cross', lupine) as tolerant to fluoride treatment at the seedling stage. 
Table 3. Total chlorophyll and carotenoids in the seedlings of different species growing under stress conditions induced with 10 mM NaF

Tabela 3. Zawartość chlorofilu całkowitego i karotenoidów w siewkach różnych gatunków roślin rosnących w warunkach stresu wywołanego przez zastosowanie $10 \mathrm{mM} \mathrm{NaF}$

\begin{tabular}{|c|c|c|c|c|c|c|}
\hline \multirow{2}{*}{$\begin{array}{l}\text { Plant species } \\
\text { Gatunek rośliny }\end{array}$} & \multicolumn{3}{|c|}{$\begin{array}{l}\text { Total chlorophyll } \\
\text { Chlorofil całkowity }\left[\mu \mathrm{g} \cdot \mathrm{g}^{-1}\right]\end{array}$} & \multicolumn{3}{|c|}{$\begin{array}{l}\text { Carotenoids } \\
\text { Karotenoidy }\left[\mu \mathrm{g} \cdot \mathrm{g}^{-1}\right]\end{array}$} \\
\hline & $\begin{array}{c}\text { control } \\
\text { kontrola }\end{array}$ & $10 \mathrm{mM} \mathrm{NaF}$ & $\mathrm{LSD}_{0.05}$ & $\begin{array}{l}\text { control } \\
\text { kontrola }\end{array}$ & $10 \mathrm{mM} \mathrm{NaF}$ & LSD $_{0.05}$ \\
\hline $\begin{array}{l}\text { Radish - Rzodkiew zwyczajna (Raphanus sativus L. cv. } \\
\text { 'Carmen') }\end{array}$ & $367.42 \pm 3.41$ & $243.77 \pm 5.61$ & $8.94^{*}$ & $64.76 \pm 0.34$ & $22.19 \pm 0.95$ & $1.39^{*}$ \\
\hline $\begin{array}{l}\text { Radish - Rzodkiew zwyczajna (Raphanus sativus L. cv. } \\
\text { 'Minowase Summer Cross') }\end{array}$ & $245.30 \pm 7.21$ & $187.66 \pm 15.60$ & $12.45^{*}$ & $29.15 \pm 0.88$ & $20.01 \pm 2.04$ & $3.03^{*}$ \\
\hline $\begin{array}{l}\text { Barley - Jęczmień zwyczajny (Hordeolum vulgare L. cv. } \\
\text { 'Eunova') }\end{array}$ & $206.99 \pm 10.88$ & $178.69 \pm 4.54$ & $16.91^{*}$ & $33.60 \pm 1.59$ & $32.39 \pm 1.25$ & n.d. \\
\hline Rye - Żyto zwyczajne (Secale cereale L. cv. 'Bojko') & $376.97 \pm 17.26$ & $321.89 \pm 7.23$ & $13.97^{*}$ & $31.91 \pm 10.05$ & $28.03 \pm 1.91$ & n.d. \\
\hline $\begin{array}{l}\text { Wheat - Pszenica zwyczajna (Triticum aestivum L. cv. } \\
\text { 'Bryza') }\end{array}$ & $612.05 \pm 20.76$ & $308.46 \pm 21.14$ & $40.37^{*}$ & $86.91 \pm 3.59$ & $50.89 \pm 3.72$ & $7.04^{*}$ \\
\hline $\begin{array}{l}\text { Blue lubine - Łubin wąskolistny (Lupinus angustifolius L. } \\
\text { cv. 'Caro') }\end{array}$ & $359.78 \pm 18.17$ & $299.45 \pm 10.39$ & $14.37^{*}$ & $53.34 \pm 6.68$ & $39.52 \pm 0.74$ & $1.36^{*}$ \\
\hline $\begin{array}{l}\text { Sunflower - Słonecznik zwyczajny (Helianthus annuus L. } \\
\text { cv. 'Bella') }\end{array}$ & $444.03 \pm 13.60$ & $218.93 \pm 20.07$ & $27.78^{*}$ & $55.26 \pm 0.76$ & $28.63 \pm 2.75$ & $3.89^{*}$ \\
\hline Cucumber - Ogórek (Cucumis sativus L. cv. 'Ela') & $212.94 \pm 4.23$ & $228.93 \pm 9.85$ & $7.37^{*}$ & $31.65 \pm 1.88$ & $21.03 \pm 0.95$ & $1.78^{*}$ \\
\hline Alfalfa - Lucerna (Medicago sativa L. cv. 'Triade') & 381.6824 .56 & $192.56 \pm 16.32$ & $40.19^{*}$ & $68.19 \pm 1.09$ & $33.93 \pm 2.65$ & $3.91^{*}$ \\
\hline $\begin{array}{l}\text { Tomato - Pomidor (Lycopersicon esculentum L. cv. } \\
\text { 'Faworyt') }\end{array}$ & $249.18 \pm 9.33$ & $174.45 \pm 7.93$ & $16.69^{*}$ & $34.26 \pm 1.27$ & $26.51 \pm 1.63$ & $2.82^{*}$ \\
\hline
\end{tabular}

Explanations see Table 1 - Objaśnienia zob. tab. 1. 


\section{REFERENCES}

Arnon D.J., Allen M.B., Whatley F. 1956. Photosynthesis by isolated chloroplast. Bioch. Bioph. Acta 20, 449-461.

Bates L.S. 1973. Rapid determination of free proline for water-stress studies. Plant Soil. 39, 205-207.

Bhargava D., Bhardwaj N. 2010. Effect of sodium fluoride on seed germination and seedling growth of Triticum aestivum var. Raj. 4083. J. Phytol. 2(4), 41-43.

Das C., Dey U., Chakraborty D., Kumar Datta J., Kumar Mondal N. 2015. Fluoride toxicity effects in potato plant (Solanum tuberosum L.) grown in contaminated soils. Oct. J. Env. Res. 3(2), 136-143.

Datta J.K., Maitra A., Mondal N.K., Banerjee A. 2012. Studies on the impact of fluoride toxicity on germination and seedling growth of gram seed (Cicer arietinum L. cv. Anuradha). J. Stress. Physiol. Biochem. 8(1), 194-202.

Divan A.M., Oliva M.A., Ferreira F.A. 2008. Dispersal pattern of airborne emissions from an aluminium smelter in Ouro Preto, Brazil, as expressed by foliar fluoride accumulation in eight plant species. Ecol. Indic., 454-461.

Elloumi N., Abdallah F.B., Mezghani l., Rhouma A., Boukhrisb M. 2005. Effect of fluoride on almond seedling in culture solution. Fluoride 38(3), 193-198.

Gadi B.R., Pooja V., Ram A. 2012. Influence of NaF on seed germination, membrane stability and some Biochemicals content in Vigna seedlings. JCBPS 2(3), 1371-1378.

Gautam R., Bhardwaj N. 2010. Bioaccumulation of fluoride in different plant parts of Hordeum vulgare (barley) var. rd-2683 from irrigation water. Fluoride 43(1), 57-60.

Gulzar S., Khan M.A. 2001. Seed germination of a halophytic grass Aeluropus logopoides. Ann. Bot. 87, 319-324.

Gupta S., Banerjee S., Mondal S. 2009. Fluoride phytotoxicity in the germination of paddy. Fluoride 42(2), 142-146.

Hadujue J. 1966. Reaction of some relativity resistant plants to sudden increase in the concentration of fluoride exhalation. Biolozia 21, 421-427.

Hager A., Mayer-Berthenrath T. 1966. Die Isolierung und quanttative Bestimung der Carotenoide und Chlorophyll von Blatern, Algen und isolierten Chloroplasten mit Hilfe Dunnschicht-chromatographischer Methoden [Isolation and quantitative determination of carotenoids and chlorophylls of leaves, algae and isolated chloroplasts using thin-layer chromatographic methods]. Planta 69, 198-217. [in German]

Ivinskis M., Murray F. 1984. Associations between metabolic injury and fluoride susceptibility in two species of Eucalyptus. Environ. Poll. 34(3), 207-23.

Jacobson J.S., Weinstein L.H., McCune D.C., Hitchcock A.E. 1966. The accumulation of fluoride by plants. JAPCA 16, 412-417.

Jha S.K., Damodaran T., Verma C.L., Mishra V.K., Sharma D.K., Sah V., Rai R.B., Dhama K. 2013. Fluoride partitioning in rice (Oryza sativa) and wheat (Triticum aestivum) upon irrigation with fluoride-contaminated water and its risk assessment. SAJEB 3(3), 137-144.

Lichtenchaler H.K, Wellburn A.R. 1983. Determinations of total carotenoids and chlorophylls $a$ and $b$ of leaf extracts in different solvents. Bioch. Soc. Trans.11, 591-592.

McNulty I.B., Newman D.W. 1961. Mechanism of fluoride induced chlorosis. Plant Physiol. 30(4), 385-388.

Pant S., Pant P., Bhiravamurthy P.V. 2008. Effects of fluoride on early root and shoot growth of typical crop plants of India. Fluoride 41(1), 57-60.

Rubio-Casal A.E., Castillo J.M., Luque C.J., Figueroa M.E. 2003. Influence of salinity on germination and seeds viability of two primary colonizers of Mediterranean salt pans. J. Arid. Environ. 53, 145-154.

Sabal D., Khan T.I., Saxena R. 2006. Effect of sodium fluoride on cluster bean (Cyamopsis tetragonoloba) seed germination and seedling growth. Fluoride 39(3), 228-30. 
Sant'Anna-Santos B.F., Azevedo A.A., Alves T.G., Campos N.V., Oliva M.A., Valente V.M.M. 2013. Effects of emissions from an aluminium smelter in a tree tropical species sensitive to fluoride. Water Air Soil Poll. 225, 1817.

Wang S.Y., Jiao H.J., Faust M. 1991. Changes in the activities of catalase, peroxidase and polyphenol oxidase in apple buds during bud break induced by thidiazuron. J. Plant Growth Regul. 10(1-4), 33-39.

Wilde L.G., Yu M. 1998. Effect of fluoride on superoxide dismutase (SOD) activity in germinating mung bean seedlings. Fluoride 31(2), 81-88.

Abstract. Fluorine is one of the most toxic elements for plants resulting from its high electronegativity. Fluorine compounds, the penetration into the plant tissue, may cause a variety of physiological and biochemical changes. The aim of this study was to determine the influence of $10 \mathrm{mM}$ sodium chloride (NaF) on morphological parameters (root length, shoot length) and physiological parameters (proline, total chlorophyll and carotenoids) in leaves of 10-day-old seedlings of various species of crop plants under laboratory conditions. Results obtained in this experiment showed that fluoride adversely affecting the morphological parameters and physiological parameters of the test plants when compared to control. Among 10 studied plants, three species (barley, radish 'Minowase Summer Cross', lupine) indicated high tolerance to NaF compared to the other tested plants. The most sensitive to lead exposure were wheat, radish 'Carmen', alfalfa, sunflower, tomato. 